\title{
RANCANG BANGUN TRAINER SIMULASI ASPHALT MIXING PLANT (AMP) MENGGUNAKAN PROGRAMMING LOGIC CONTROL (PLC) DAN HUMAN MACHINE INTERFACE (HMI)
}

\author{
Ahmad Ridwan Nur Saputra ${ }^{1}$, Asep Andang ${ }^{2}$, Abdul Chobir ${ }^{3}$ \\ Jurusan Teknik elektro, Fakultas Teknik, Universitas Siliwangi ${ }^{1,2,3}$ \\ email: ahmad.ridwan.nursaputra@gmail.com ${ }^{1}$
}

\begin{abstract}
The development of learning media in world education in the industrial era 4.0 is a priority as a means of practicum activities carried out so that students can understand the lessons presented. With technology that develops rapidly and is fully automated, it is hoped that students can understand how a system works.This study aims to create a practical tool that can simplify the Asphalt Mixing Plant (AMP) process using Programmable Logic Control (PLC) which can be programmed with the Human Machine Interface (HMI) screen panel as a display of working processes and to create a basic learning module for a programming language for PLCs. and HMI. The research method uses Research and Development with the ADDIE technique from Robert Maribe Branch (2009), namely: Analysis, Design, Development, Implementation, and Evaluation. From the results of the feasibility test with a total value of 51.06 and a percentage of $85 \%$ of the trainers get the "VERY FEASIBLE" category and the reliability test with an alpha value of 0.75 gets the "RELIABLE" category. The results of blackbox testing as a whole the tools that have been designed can be said to work optimally as expected as a practicum tool. The basic learning module for the programming language is easy to understand and has been approved by the supervisor.
\end{abstract}

Keywords: Asphalt Mixing Plant (AMP), PLC, HMI

\begin{abstract}
Abstrak
Perkembangan media pembelajaran pada dunia pendidikan di era industry 4.0 menjadi prioritas sebagai sarana penunjang kegiatan praktikum dilakukan sehingga mahasiswa mampu memahami pelajaran yang disampaikan. Dengan teknologi yang berkembang dengan cepat dan serba otomatis, maka mahasiswa diharapkan dapat memahami cara kerja suatu sistem. Penelitian ini bertujuan untuk membuat alat praktikum yang dapat menyimulasikan proses Asphalt Mixing Plant (AMP) menggunakan Programmable Logic Control (PLC) yang dapat diprogram dengan layar panel Human Machine Interface (HMI) sebagai tampilan proses yang bekerja serta membuat modul pembelajaran dasar bahasa pemrograman untuk PLC dan HMI. Metode penelitian menggunakan Research and Development dengan teknik ADDIE [6] yaitu: Analisis, Desain, Develop, Implementasi, dan Evaluasi. Dari hasil pengujian kelayakan dengan total nilai 51,06 dan persentase $85 \%$ trainer mendapat kategori "SANGAT LAYAK" serta pengujian reliabilitas dengan nilai alpha 0,75 mendapat kategori "RELIABEL". Hasil pengujian blackbox secara keseluruhan alat yang telah dirancang dapat dikatakan bekerja secara optimal sesuai dengan yang diharapkan sebagai alat praktikum. Modul pembelajaran dasar bahasa pemrograman mudah dipahami dan telah disetujui oleh dosen pembimbing.
\end{abstract}

Kata Kunci: Asphalt Mixing Plant (AMP), PLC, HMI.

\section{PENDAHULUAN}

Dalam dunia pendidikan yang optimal meliputi proses pengajaran teori dan proses pengajaran praktek. Proses pembelajaran praktikum membutuhkan alat bantu pengajaran atau disebut alat peraga pendidikan (teaching aid). Fungsi alat peraga pendidikan adalah suatu alat yang dapat diserap oleh mata dan telinga dengan tujuan membantu guru agar proses belajar mengajar siswa lebih efektif dan efisien [1].

Seiring dengan perkembangan teknologi yang serba otomasi, mahasiswa lulusan universitas siliwangi jurusan teknik elektro dituntut untuk dapat memahami dasar teknologi otomasi. Teknologi otomasi yang dimasukkan pada pembelajaran di universitas siliwangi jurusan teknik elektro yaitu pada mata kuliah PLC. Kegiatan pembelajaran ini masuk pada jenjang mahasiswa dikarenakan kebutuhan dari industri agar mahasiswa teknik elektro mampu bersaing di dunia industri.

\section{TINJAUAN PUSTAKA}

\section{A. Trainer}

Trainer adalah suatu set peralatan di laboratorium yang digunakan sebagai sarana praktikum yang dapat meningkatkan keterampilan peserta didik [2]. Trainer digunakan untuk menunjang pembelajaran peserta didik dalam menerapkan pengetahuan/konsep-konsep yang diperolehnya pada benda nyata sehingga dapat meningkatkan keterampilan siswa dalam praktikum.

B. Asphalt Mixing Plant (AMP)

Asphalt mixing plant (unit produksi campuran beraspal) adalah seperangkat peralatan mekanik dan elektronik dimana agregat dipanaskan, dikeringkan dan dicampur dengan aspal untuk menghasilkan campuran beraspal panas yang memenuhi persyaratan tertentu, AMP dapat terletak di lokasi yang permanen atau berpindah dari satu tempat ke tempat lain [3].

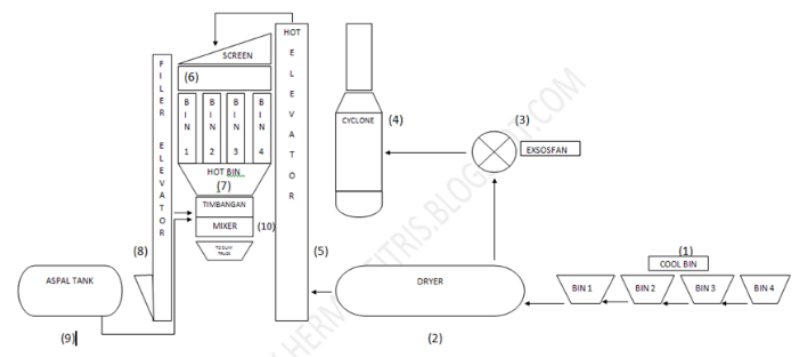

Gbr 1 Proses Asphalt Mixing Plant

C. Programmable Logic Control (PLC)

Definisi Programmable Logic Controller menurut Capiel adalah sistem elektronik yang beroperasi secara dijital dan didisain untuk pemakaian di lingkungan industri, dimana sistem ini menggunakan memori yang dapat diprogram 
untuk penyimpanan secara internal instruksi-instruksi yang mengimplementasikan fungsi-fungsi spesifik seperti logika, urutan, waktu, pencacahan dan operasi aritmatik untuk mengontrol mesin atau proses melalui modul-modul I/O digital maupun analog [4].

\section{Human Machine Interface (HMI)}

HMI (Human Machine Interface) merupakan perangkat lunak antar muka berupa GUI berbasis komputer yang menjadi penghubung antara operator dengan mesin atau peralatan yang dikendalikan serta bertindak pada supervisory [5].

\section{METODE}

Penelitian ini menggunakan model penelitian dan pengembangan ADDIE menurut Robert Maribe Branch. ADDIE merupakan singkatan dari Analysis, Design, Develop, Implement, dan Evaluate. Berikut merupakan diagram beserta Tbl penjelasan model penelitian dan pengembangan ADDIE menurut Robert Maribe Branch:

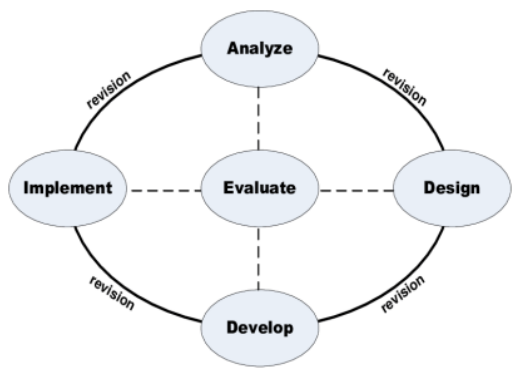

Gbr 2 Konsep ADDIE menurut Robert Maribe Branch

\section{A. Flowchart Penelitian}

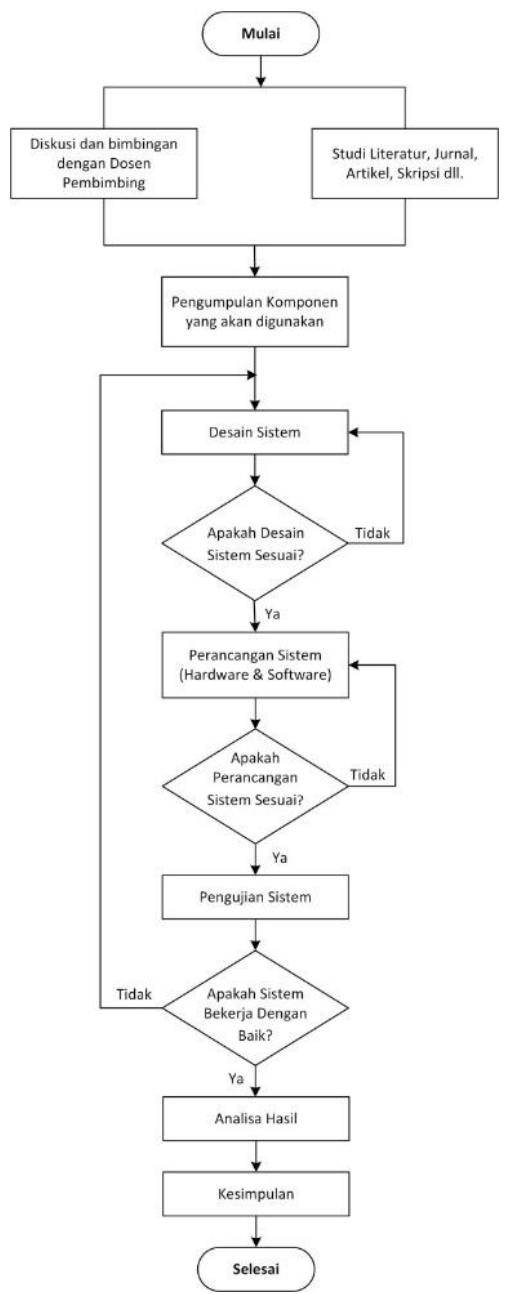

Gbr 3 Flowchart Penelitian

\section{B. Desain Sistem}

\section{1) Blok Diagram Sistem}

Blok diagram adalah suatu kesatuan dari bagian yang tersusun sesuai dengan kebutuhan. Bagian tersebut terdiri dari blok berwarna merah yang menunjukan sumber tegangan 220 VAC ke catu daya yang berwarna biru sebagai masukan dan mengeluarkan tegangan 24 VDC untuk memberi tegangan pada blok berwarna hijau yaitu PLC dan HMI. Dimana PLC dan HMI dapat berkomunikasi menggunakan RS-232. Sedangkan blok berwarna kuning input device untuk memberikan masukan dari perangkat luar ke PLC untuk diproses dan blok berwarna oranye output device untuk memberikan hasil dari proses PLC.

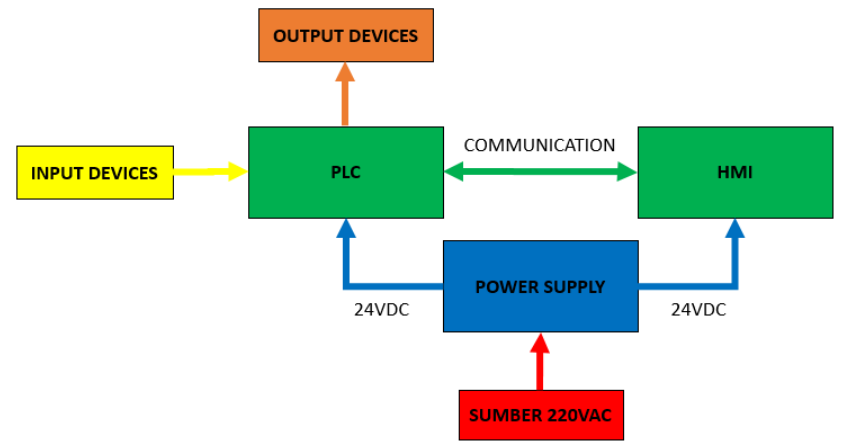

Gbr 4. Blok Diagram Sistem 


\section{Flowchart Sistem}

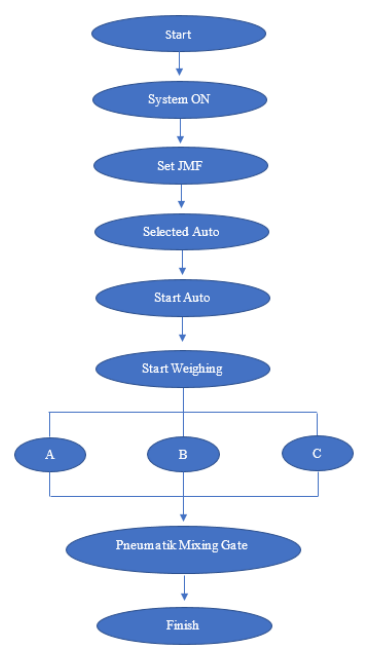

Gbr 5 Flowchart Sistem

D. Perancangan Perangkat Keras

1) Catu Daya

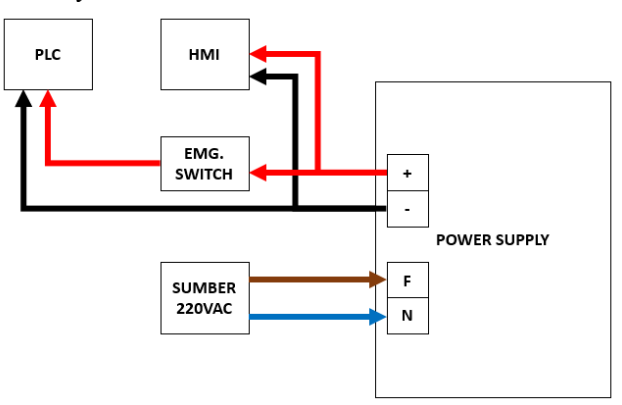

Gbr 6. Blok Diagram Catu Daya

\section{2) Programmable Logic Control}

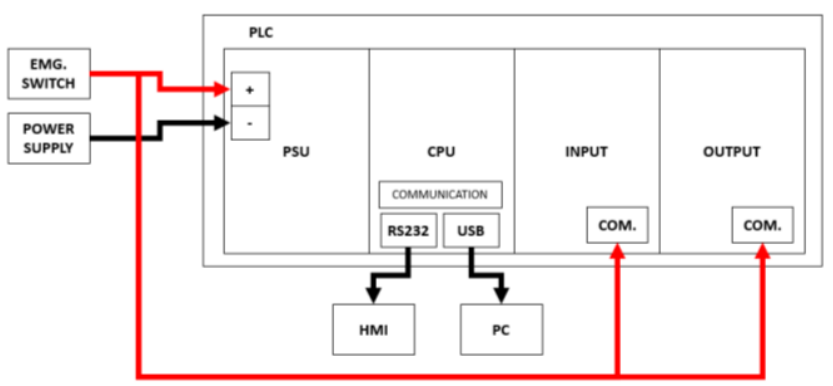

Gbr 7 Blok Diagram PLC

\section{3) Human Machine Interface}

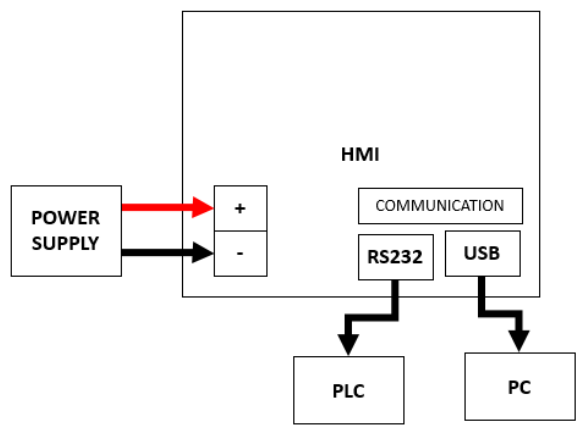

Gbr 8 Blok Diagram HMI

\section{E. Teknik Analisis Data}

Teknik analisis data yang digunakan adalah teknik analisis deskriptif, guna mengetahui tingkat kelayakan produk. Analisis data tersebut diperoleh dengan menggunakan angket dengan skala Likert empat pilihan, yaitu: sangat setuju, setuju, tidak setuju, dan sangat tidak setuju. Berikut urutan proses analisis data yang dilakukan meliputi:

1. Menentukan kelas interval yang berjumlah empat antara lain sangat setuju, setuju, tidak setuju, dan sangat tidak setuju.

2. Menentukan skor minimum dan skor maksimum dengan rumus:

$$
\begin{aligned}
& S_{\text {min }}=1 \times \text { Jumlah butir } \\
& S_{\text {max }}=4 \times \text { Jumlah butir }
\end{aligned}
$$

3. Menentukan mean dan standar deviasi dengan rumus:

$$
\begin{aligned}
& X_{i}=\frac{\left(S_{\max }+S_{\min }\right)}{2} \\
& S b_{i}=\frac{\left(S_{\max }-S_{\min }\right)}{6}
\end{aligned}
$$

\begin{tabular}{|c|c|}
\hline Rumus & Kategori Penilaian \\
\hline $\begin{array}{l}X \\
>X_{i}+1,8 \times S b_{i}\end{array}$ & $\begin{array}{c}\text { Sangat Layak / Sangat } \\
\text { Baik }\end{array}$ \\
\hline $\begin{array}{l}X_{i}+0,6 \times S b_{i} \\
<X \\
\leq X_{i}+1,8 \times S b_{i}\end{array}$ & Layak / Baik \\
\hline $\begin{array}{l}X_{i}-0,6 \times{S b_{i}} \\
<X \\
\leq X_{i}+0,6 \times S b_{i}\end{array}$ & $\begin{array}{c}\text { Cukup Layak / Cukup } \\
\text { Baik }\end{array}$ \\
\hline $\begin{array}{l}X_{i}-1,8 \times S b_{i} \\
<X \\
\leq X_{i}-0,6 \times S b_{i}\end{array}$ & $\begin{array}{c}\text { Kurang Layak / Kurang } \\
\text { Baaik }\end{array}$ \\
\hline $\begin{array}{l}X \\
\leq X_{i}-1,8 \times S b_{i}\end{array}$ & $\begin{array}{c}\text { Sangat Kurang Layak / } \\
\text { Sangat Kurang Baik }\end{array}$ \\
\hline
\end{tabular}

Tbl 1 Kriteria Kelayakan Media Pembelajaran (Sugeng, 2016:238).

Instrumen yang reliabel adalah instrumen yang bila digunakan beberapa kali untuk mengukur objek yang sama, akan menghasilkan data yang sama [7]. Dengan kata lain uji reliabilitas adalah pengujian instrumen untuk menentukan tingkat konsistensi instrumen tersebut dalam pengambilan data. Rumus yang digunakan untuk mencari reiabilitas instrumen pada penelitian ini menggunakan rumus Alpha Cronbach.

Dalam teknik Alpha Cronbach [8], Kriteria satu instrumen dikatakan reliabel adalah apabila memiliki koefisien reliabel $\left(r_{11}\right)=>0,6$. Tahapan pengujian menggunakan teknik Alpha Cronbach, yaitu:

a. Menentukan nilai varians setiap butir pertanyaan

$$
\sigma_{b}{ }^{2}=\frac{\sum X_{i}^{2}-\frac{\left(\sum X_{i}\right)^{2}}{n}}{n}
$$

b. Menentukan nilai varians total

$$
\sigma_{t}^{2}=\frac{\sum X^{2}-\frac{\left(\sum X\right)^{2}}{n}}{n}
$$

c. Menentukan reliabel instrumen 


$$
r_{11}=\left[\frac{k}{(k-1)}\right]\left[1-\frac{\sum \sigma_{b}^{2}}{\sigma_{t}^{2}}\right]
$$

Keterangan:

$\mathrm{n} \quad=$ Jumlah sampel

$\mathrm{X} \quad=$ Nilai skor yang dipilih

$r_{11}=$ koefisien reliabilitas intrumen

$\mathrm{k} \quad=$ banyaknya butir pertanyaan atau banyaknya soal

$\sum \sigma_{b}^{2}=$ jumlah varians butir

$\sigma_{t}^{2} \quad=$ varians total

Setelah diketahui koefisien realibitas instrumen, kemudian diukur tingkat reliabilitas berdasarkan nilai alpha menurut Triton [9].

Tbl 2 Tingkat Reliabilitas Berdasarkan Nilai Alpha

\begin{tabular}{cc}
\hline Alpha & Tingkat Reliabilitas \\
\hline 0,00 s.d. 0,20 & Kurang Reliabel \\
\hline$>\mathbf{0 , 2 0}$ s.d. 0,40 & Agak Reliabel \\
\hline$>\mathbf{0 , 4 0}$ s.d. 0,60 & Cukup Reliabel \\
\hline$>$ 0,60 s.d. 0,80 & Reliabel \\
\hline$>$ 0,80 s.d. 1,00 & Sangat Reliabel \\
\hline
\end{tabular}

\section{HASIL DAN PEMBAHASAN}

\section{A. Hasil Desain}

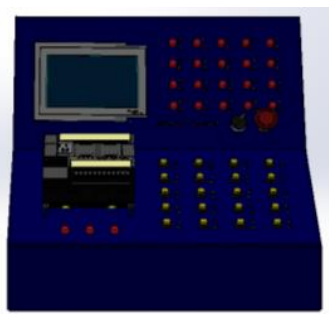

Gbr 9. Desain Menggunakan Solidworks

\section{B. Hasil Develop}

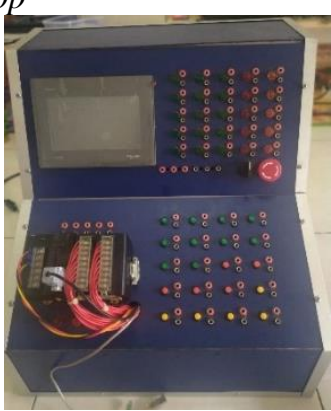

Gbr 10. Hasil Perakitan Sesuai Desain

\section{Hasil Implementasi}

1) Pengujian Trainer

Pengujian yang dilakukan yaitu pengujian catu daya, pengujian Input dan Output PLC, Pengujian HMI. Pengujian dilakukan selama tiga hari. Berikut hasil pengujian catu daya

Tbl 3 Hasil Pengujian Catu Daya Hari ke-1 (Rabu, 10-02-2021)

\begin{tabular}{ccc}
\hline \multirow{2}{*}{$\begin{array}{c}\text { Pengujian } \\
\text { Ke- }\end{array}$} & \multicolumn{2}{c}{ Hasil Pengukuran (volt) } \\
\cline { 2 - 3 } & Teg. Masuk (VAC) & Teg. Keluar (VDC) \\
\hline $\mathbf{1}$ & 226,40 & 24,34 \\
\hline $\mathbf{2}$ & 226,50 & 24,30 \\
\hline
\end{tabular}

\begin{tabular}{ccc}
\hline $\mathbf{3}$ & 226,20 & 24,36 \\
\hline $\mathbf{4}$ & 226,60 & 24,36 \\
\hline $\mathbf{5}$ & 226,50 & 24,47 \\
\hline Rata-rata & 226,44 & 24,37 \\
\hline
\end{tabular}

Tbl 4 Hasil Pengujian Catu Daya Hari ke-2 (Jum'at, 12-02-2021)

\begin{tabular}{ccc}
\hline $\begin{array}{c}\text { Pengujian } \\
\text { Ke- }\end{array}$ & \multicolumn{2}{c}{ Hasil Pengukuran (volt) } \\
\cline { 2 - 3 } & Teg. Masuk (VAC) & Teg. Keluar (VDC) \\
\hline $\mathbf{1}$ & 227,60 & 24,33 \\
\hline $\mathbf{2}$ & 227,60 & 24,34 \\
\hline $\mathbf{3}$ & 227,20 & 24,34 \\
\hline $\mathbf{4}$ & 227,30 & 24,35 \\
\hline $\mathbf{5}$ & 227,30 & 24,35 \\
\hline Rata-rata & 227,40 & 24,34 \\
\hline
\end{tabular}

Tbl 5 Hasil Pengujian Catu Daya Hari ke-3 (Senin, 15-02-2021)

\begin{tabular}{ccc}
\hline $\begin{array}{c}\text { Pengujian } \\
\text { Ke- }\end{array}$ & \multicolumn{2}{c}{ Hasil Pengukuran (volt) } \\
\cline { 2 - 3 } & Teg. Masuk (VAC) & Teg. Keluar (VDC) \\
\hline $\mathbf{1}$ & 227,80 & 24,32 \\
\hline $\mathbf{2}$ & 227,90 & 24,33 \\
\hline $\mathbf{3}$ & 227,80 & 24,33 \\
\hline $\mathbf{4}$ & 227,60 & 24,34 \\
\hline $\mathbf{5}$ & 227,60 & 24,35 \\
\hline Rata-rata & 227,74 & 24,334
\end{tabular}

Pengujian lain yang dilakukan yaitu pengujian pada Input dan Output PLC. Pengujian ini dilakukan untuk mengetahui apakah komponen dan rangkaian berfungsi dengan baik atau tidak.

Tbl 6 Hasil Pengujian Input PLC Hari ke-1 (Rabu, 10-02-2021)

\begin{tabular}{llll}
\hline No. & INPUT & Keterangan & \multicolumn{2}{l}{ Berfungsi } \\
\cline { 4 - 4 } & & & Ya Tidak \\
\hline 1. & 0.00 & Auto & $\checkmark$ \\
\hline 2. & 0.01 & Start & $\checkmark$ \\
\hline 3. & 0.02 & Mixer Run & $\checkmark$ \\
\hline 4. & 0.03 & Asphalt Transfer Forward & $\checkmark$ \\
\hline 5. & 0.04 & Compressor Run & $\checkmark$ \\
\hline 6. & 0.05 & Open Aggregate Weighing Manual & $\checkmark$ \\
\hline 7. & 0.06 & Open Mixer Manual & $\checkmark$ \\
\hline 8. & 0.07 & Stop & $\checkmark$ \\
\hline 9. & 0.08 & Open Bin 1 Manual & $\checkmark$ \\
\hline 10. & 0.09 & Open Bin 2 Manual & $\checkmark$ \\
\hline 11. & 0.10 & Open Bin 3 Manual & $\checkmark$ \\
\hline 12. & 0.11 & Open Bin 4 Manual & $\checkmark$ \\
\hline 13. & 0.12 & Open Asphalt Manual & $\checkmark$ \\
\hline 14. & 0.13 & Open Filler Manual & $\checkmark$ \\
\hline 15. & 0.14 & Open Gate Asphalt Manual & $\checkmark$ \\
\hline 16. & 0.15 & Open Gate Filler Manual & $\checkmark$
\end{tabular}


Tbl 7 Hasil Pengujian Output PLC Hari ke-1

$$
\text { (Rabu, 10-02-2021) }
$$

\begin{tabular}{|c|c|c|c|}
\hline \multirow[t]{2}{*}{ No. } & \multirow[t]{2}{*}{ OUTPUT } & \multirow[t]{2}{*}{ Keterangan } & Berfungsi \\
\hline & & & Ya $\quad$ Tidak \\
\hline 1. & 1.00 & Indicator Auto & $\checkmark$ \\
\hline 2. & 1.01 & Indicator Stop & $\checkmark$ \\
\hline 3. & 1.02 & Indicator Start & $\checkmark$ \\
\hline 4. & 1.03 & Indicator Mixer Run & $\checkmark$ \\
\hline 5. & 1.04 & $\begin{array}{lll}\text { Indicator } & \text { Asphalt } & \text { Trasnfer } \\
\text { Forward } & & \\
\end{array}$ & $\checkmark$ \\
\hline 6. & 1.05 & Indicator Compressor & $\checkmark$ \\
\hline 7. & 1.06 & $\begin{array}{lll}\begin{array}{l}\text { Indicator } \\
\text { Aggregate }\end{array} & \text { Open } & \text { Weighing } \\
\end{array}$ & $\checkmark$ \\
\hline 8. & 1.07 & Indicator Open Bin 1 & $\checkmark$ \\
\hline 9. & 1.08 & Indicator Open Bin 2 & $\checkmark$ \\
\hline 10. & 1.09 & Indicator Open Bin 3 & $\checkmark$ \\
\hline 11. & 1.10 & Indicator Open Bin 4 & $\checkmark$ \\
\hline 12. & 1.11 & Indicator Open Asphalt & $\checkmark$ \\
\hline 13. & 1.12 & Indicator Asphalt Gate Weighing & $\checkmark$ \\
\hline 14. & 1.13 & Indicator Open Filler & $\checkmark$ \\
\hline 15. & 1.14 & Indicator Filler Gate Weighing & $\checkmark$ \\
\hline 16. & 1.15 & Indicator Mixing Gate & $\checkmark$ \\
\hline 17. & 2.00 & End Indicator & $\checkmark$ \\
\hline
\end{tabular}

Tbl 8 Hasil Pengujian Input PLC Hari ke-2 (Jum'at, 12-02-2021)

\begin{tabular}{|c|c|c|c|}
\hline \multirow[t]{2}{*}{ No. } & \multirow[t]{2}{*}{ INPUT } & \multirow[t]{2}{*}{ Keterangan } & Berfungsi \\
\hline & & & Tidak \\
\hline 1. & 0.00 & Auto & $\checkmark$ \\
\hline 2. & 0.01 & Start & $\checkmark$ \\
\hline 3. & 0.02 & Mixer Run & $\checkmark$ \\
\hline 4. & 0.03 & Asphalt Transfer Forward & $\checkmark$ \\
\hline 5. & 0.04 & Compressor Run & $\checkmark$ \\
\hline 6. & 0.05 & Open Aggregate Weighing Manual & $\checkmark$ \\
\hline 7. & 0.06 & Open Mixer Manual & $\checkmark$ \\
\hline 8. & 0.07 & Stop & $\checkmark$ \\
\hline 9. & 0.08 & Open Bin 1 Manual & $\checkmark$ \\
\hline 10. & 0.09 & Open Bin 2 Manual & $\checkmark$ \\
\hline 11. & 0.10 & Open Bin 3 Manual & $\checkmark$ \\
\hline 12. & 0.11 & Open Bin 4 Manual & $\checkmark$ \\
\hline 13. & 0.12 & Open Asphalt Manual & $\checkmark$ \\
\hline 14. & 0.13 & Open Filler Manual & $\checkmark$ \\
\hline 15. & 0.14 & Open Gate Asphalt Manual & $\checkmark$ \\
\hline 16. & 0.15 & Open Gate Filler Manual & $\checkmark$ \\
\hline
\end{tabular}

Tbl 9 Hasil Pengujian Output PLC Hari ke-2 (Jum'at, 12-02-2021)

\begin{tabular}{llll}
\hline No. & OUTPUT & Keterangan & \multicolumn{2}{l}{ Berfungsi } \\
\cline { 3 - 4 } & & Ya Tidak \\
\hline 1. & 1.00 & Indicator Auto & $\checkmark$ \\
\hline 2. & 1.01 & Indicator Stop & $\checkmark$ \\
\hline 3. & 1.02 & Indicator Start & $\checkmark$ \\
\hline 4. & 1.03 & Indicator Mixer Run & $\checkmark$
\end{tabular}

\begin{tabular}{|c|c|c|c|}
\hline 5. & 1.04 & $\begin{array}{l}\text { Indicator Asphalt } \quad \text { Trasnfer } \\
\text { Forward }\end{array}$ & $\checkmark$ \\
\hline 6. & 1.05 & Indicator Compressor & $\checkmark$ \\
\hline 7. & 1.06 & $\begin{array}{l}\text { Indicator } \\
\text { Aggregate }\end{array} \quad$ Open $\quad$ Weighing & $\checkmark$ \\
\hline 8. & 1.07 & Indicator Open Bin 1 & $\checkmark$ \\
\hline 9. & 1.08 & Indicator Open Bin 2 & $\checkmark$ \\
\hline 10. & 1.09 & Indicator Open Bin 3 & $\checkmark$ \\
\hline 11. & 1.10 & Indicator Open Bin 4 & $\checkmark$ \\
\hline 12. & 1.11 & Indicator Open Asphalt & $\checkmark$ \\
\hline 13. & 1.12 & Indicator Asphalt Gate Weighing & $\checkmark$ \\
\hline 14. & 1.13 & Indicator Open Filler & $\checkmark$ \\
\hline 15. & 1.14 & Indicator Filler Gate Weighing & $\checkmark$ \\
\hline 16. & 1.15 & Indicator Mixing Gate & $\checkmark$ \\
\hline 17. & 2.00 & End Indicator & $\checkmark$ \\
\hline
\end{tabular}

Tbl 10 Hasil Pengujian Input PLC Hari ke-3 (Senin, 15-02-2021)

\begin{tabular}{llll}
\hline No. & INPUT & Keterangan & \multicolumn{2}{l}{ Berfungsi } \\
\cline { 4 - 4 } & & & Ya Tidak \\
\hline 1. & 0.00 & Auto & $\checkmark$ \\
\hline 2. & 0.01 & Start & $\checkmark$ \\
\hline 3. & 0.02 & Mixer Run & $\checkmark$ \\
\hline 4. & 0.03 & Asphalt Transfer Forward & $\checkmark$ \\
\hline 5. & 0.04 & Compressor Run & $\checkmark$ \\
\hline 6. & 0.05 & Open Aggregate Weighing Manual & $\checkmark$ \\
\hline 7. & 0.06 & Open Mixer Manual & $\checkmark$ \\
\hline 8. & 0.07 & Stop & $\checkmark$ \\
\hline 9. & 0.08 & Open Bin 1 Manual & $\checkmark$ \\
\hline 10. & 0.09 & Open Bin 2 Manual & $\checkmark$ \\
\hline 11. & 0.10 & Open Bin 3 Manual & $\checkmark$ \\
\hline 12. & 0.11 & Open Bin 4 Manual & $\checkmark$ \\
\hline 13. & 0.12 & Open Asphalt Manual & $\checkmark$ \\
\hline 14. & 0.13 & Open Filler Manual & $\checkmark$ \\
\hline 15. & 0.14 & Open Gate Asphalt Manual & $\checkmark$ \\
\hline 16. & 0.15 & Open Gate Filler Manual & $\checkmark$ \\
\hline & & &
\end{tabular}

Tbl 11 Hasil Pengujian Output PLC Hari ke-3 (Senin, 15-02-2021)

\begin{tabular}{lllll} 
No. & OUTPUT & Keterangan & \multicolumn{2}{l}{ Berfungsi } \\
\cline { 3 - 4 } & & & Ya Tidak \\
\hline 1. & 1.00 & Indicator Auto & $\checkmark$ \\
\hline 2. & 1.01 & Indicator Stop & $\checkmark$ \\
\hline 3. & 1.02 & Indicator Start & $\checkmark$ \\
\hline 4. & 1.03 & Indicator Mixer Run & $\checkmark$ \\
\hline 5. & 1.04 & Indicator Asphalt & Trasnfer & $\checkmark$ \\
\hline 6. & 1.05 & Indicator Compressor & $\checkmark$ \\
\hline 7. & 1.06 & $\begin{array}{l}\text { Indicator Open } \\
\text { Aggregate }\end{array}$ & Weighing & $\checkmark$ \\
\hline 8. & 1.07 & Indicator Open Bin 1 & $\checkmark$ \\
\hline 9. & 1.08 & Indicator Open Bin 2 & $\checkmark$ \\
\hline 10. & 1.09 & Indicator Open Bin 3 & $\checkmark$ \\
\hline 11. & 1.10 & Indicator Open Bin 4 & $\checkmark$ \\
\hline & & & \\
\hline
\end{tabular}




\begin{tabular}{llll}
\hline 12. & 1.11 & Indicator Open Asphalt & $\checkmark$ \\
\hline 13. & 1.12 & Indicator Asphalt Gate Weighing & $\checkmark$ \\
\hline 14. & 1.13 & Indicator Open Filler & $\checkmark$ \\
\hline $\mathbf{1 5}$. & 1.14 & Indicator Filler Gate Weighing & $\checkmark$ \\
\hline $\mathbf{1 6}$ & 1.15 & Indicator Mixing Gate & $\checkmark$ \\
\hline $\mathbf{1 7}$ & 2.00 & End Indicator & $\checkmark$ \\
\hline
\end{tabular}

Pengujian HMI dilakukan dengan cara ditekan tombol yang terdapat pada layar HMI. Tujuan dari pengujian HMI yaitu apakah komunikasi antara HMI dengan PLC dapat berfungsi dengan baik atau tidak. Pengujian HMI dilakukan bersama Mahasiswa Teknik Elektro Universitas Siliwangi yang dapat dilihat pada Gbr 11a dan 11 b.

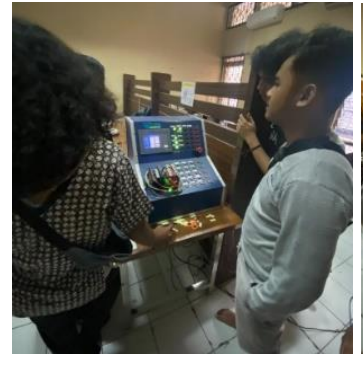

a

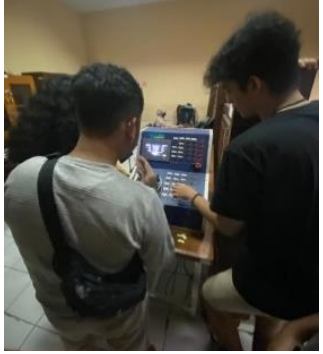

b
Gbr 11a dan 11b Pengujian Kelayakan dan Reliabilitas Oleh Mahasiswa Teknik Elektro UNSIL

\section{Hasil Evaluasi}

Tingkat kelayakan media pembelajaran menurut pengguna ditinjau dari hasil implementasi media pembelajaran pada Mahasiswa Fakultas Teknik Elektro Universitas Siliwangi. Penilaian pada kelompok kecil dilakukan dengan melibatkan 16 Mahasiswa untuk menjadi responden. Data hasil penilaian tersebut kemudian akan diakumulasikan dan kemudian dibandingkan dengan kategori kelayakan media pembelajaran. Kategori kelayakan trainer dapat dilihat pada Tbl 12.

Tbl 12 Kategori Kelayakan Media Pembelajaran

\begin{tabular}{ccccc}
\hline $\begin{array}{c}\text { Kategori } \\
\text { Penilaian }\end{array}$ & $\begin{array}{c}\text { Interval } \\
\text { Aspek } \\
\text { Kualitas } \\
\text { Isi dan } \\
\text { Tujuan }\end{array}$ & $\begin{array}{c}\text { Interval } \\
\text { Aspek } \\
\text { Pengguna } \\
\text { an }\end{array}$ & $\begin{array}{c}\text { Interval } \\
\text { Aspek } \\
\text { Pembelaja } \\
\text { ran }\end{array}$ & $\begin{array}{c}\text { Keselu } \\
\text { ruhan }\end{array}$ \\
\hline Sangat & $20<\mathrm{X} \leq$ & $14<\mathrm{X} \leq$ & $17<\mathrm{X} \leq$ & $51<\mathrm{X}$ \\
Layak & 24 & 16 & 20 & $\leq 60$ \\
\hline Layak & $17<\mathrm{X} \leq$ & $11<\mathrm{X} \leq$ & $14<\mathrm{X} \leq$ & $42<\mathrm{X}$ \\
& 20 & 14 & 17 & $\leq 51$ \\
\hline Cukup & $13<\mathrm{X} \leq$ & $9<\mathrm{X} \leq$ & $11<\mathrm{X} \leq$ & $33<\mathrm{X}$ \\
Layak & 17 & 11 & 14 & $\leq 42$ \\
\hline Kurang & $10<\mathrm{X} \leq$ & $6<\mathrm{X} \leq 9$ & $8<\mathrm{X} \leq 11$ & $24<\mathrm{X}$ \\
Layak & 13 & & & $\leq 33$ \\
\hline Sangat & $6<\mathrm{X}<$ & $4<\mathrm{X}<6$ & $5<\mathrm{X}<8$ & $15<\mathrm{X}$ \\
Kurang & 10 & & & $<24$ \\
Layak & & & & \\
\hline
\end{tabular}

Setiap aspek memiliki interval yang berbeda - beda tergantung jumlah butir penilaian dan nilai kemungkinan maksimal dari setiap butir yang ada. Perhitungan interval secara lengkap dapat dilihat pada lampiran. Data akumulasi dari siap aspek penelitian tersebut akan digunakan untuk menentukan kategori pada setiap aspek. Data hasil penilaian media pembelajaran dapat dilihat pada Tbl 13.
Tbl 13. Data Hasil Penilaian Pada Kelompok Kecil

\begin{tabular}{clcccc}
\hline No. & \multicolumn{1}{c}{ Aspek } & $\begin{array}{c}\text { Skor } \\
\text { Maks }\end{array}$ & $\begin{array}{c}\text { Skor } \\
\text { Min }\end{array}$ & $\begin{array}{c}\text { Rerata } \\
\text { Tiap } \\
\text { Aspek }\end{array}$ & $\begin{array}{c}\text { Persentase } \\
\text { Tiap } \\
\text { Aspek }\end{array}$ \\
\hline 1. & $\begin{array}{l}\text { Kualitas Isi } \\
\text { dan Tujuan }\end{array}$ & 24 & 6 & 20 & $84 \%$ \\
\hline 2. & Pembelajaran & 20 & 5 & 14 & $84 \%$ \\
\hline 3. & Penggunaan & 16 & 4 & 18 & $88 \%$ \\
\hline & Total & 60 & 15 & 51 & $85 \%$ \\
\hline
\end{tabular}

Berdasarkan diagram tersebut, pada aspek kualitas isi dan tujuan memperoleh persentase $84 \%$ dengan kategori "SANGAT LAYAK". Pada aspek kualitas pembelajaran memperoleh persentase $84 \%$ dengan kategori "SANGAT LAYAK". Pada aspek penggunaan memperoleh persentase 88\% dengan kategori "SANGAT LAYAK". Dari data tersebut dapat diperoleh nilai rata-rata penilaian kelayakan media pembelajaran sebesar 51,06 dan masuk pada kategori "SANGAT LAYAK" dengan persentase 85\%.

Data pengujian kelayakan pada angket yang dilakukan oleh 16 mahasiswa Fakultas Teknik Elektro Universitas Siliwangi dilakukan pengolahan untuk reliabilitas trainer. Sesuai dengan Tbl 3.6 dari hasil pengolahan alpha yang dihasilkan bernilai 0,75 yang termasuk pada kategori "RELIABEL". Hasil pengujian dapat dilihat lebih detil pada lampiran.

Tbl 14. Data Hasil Uji Reliabitias Pada Kelompok Kecil

\begin{tabular}{|l|l|}
\hline Evarians tiap item & 4,07 \\
\hline Varians total & 13,4 \\
\hline $\mathbf{r}_{11}$ & 0,75 \\
\hline
\end{tabular}

\section{KESIMPULAN}

Alat ini telah dirancang berdasarkan desain sistem yang telah direncanakan menggunakan Solidworks. Hasil perancangan perangkat keras (Hardware) dan perangkat lunak (Software) bekerja dengan baik sesuai dengan alur proses yang telah dibuat. Dengan dirancangnya alat ini dapat diaplikasikan untuk bahan pembelajaran dan mensimulasikan proses Asphalt Mixing Plant (AMP) sehingga pengguna dapat mengetahui setiap proses seperti pada pembuatannya. Alat ini dapat diprogram ulang pada PLC dan HMI sesuai keinginan pengguna dengan menggunakan CX-Programmer dan Vijeo Designer. Alat ini dapat menggunakan input dan output eksternal untuk mendapatkan pengalaman yang lebih baik. Modul pembelajaran yang dibuat dapat memberikan informasi tentang dasar pemrograman PLC dan HMI. Hasil uji kelayakan dari total perolehan nilai mendapat kategori "SANGAT LAYAK" dengan nilai 51,06 dan persentase $85 \%$. Hasil uji reliabilitas dari data uji kelayakan nilai alpha memperoleh 0,75 dengan kategori "RELIABEL". 


\section{REFERENSI}

[1] Sudjana, Nana. 2009. Dasar-Dasar Proses Belajar Mengajar. Bandung: Sinar Baru Algensido.

[2] Rochayati, Umi dan Suprapto, "Keefektifan Trainer Digital Berbasis Mikrokontrolerdengan Model Briefcase Dalam Pembelajaran Praktik Di SMK", Jurnal Kependidikan, Volume 44, Nomor 2, November 2014, Halaman 127-138.

[3] Departemen Pekerjaan Umum Direktorat Jenderal Bina Marga, "Manual Kontruksi dan Bangunan tentang Pemeriksaan Peralatan Unit Pencampur Aspal Panas (Asphalt Mixing Plant)", No.001/BM/2007.

[4] Capiel (1982). Programmable Logic Controllers [Online]. Tersedia : http://www.capiel.eu

[Diakses : 24 Januari 2021]

[5] Engineering360, "Human Machine Interface (HMI) Software Information”, globalspec.com, 21 April 2016. [Online]. Tersedia https://www.globalspec.com/learnmore/industrial eng ineering_software/industrial_controls_software/huma n_machine_interface_software_hmi [Diakses : 28 Januari 2021]

[6] Branch, Robert Maribe.Instructional Design : The ADDIE Approach.New York : Springer Science \& Business Media, LLC. 2009.

[7] Sugiyono. (2017). Metode Penelitian Kuantitatif, Kualiatif, dan R\&D. Bandung: ALFABETA.

[8] Syofian Siregar. (2014). Statistika Deskriptif untuk Penelitian. Jakarta: PT Raja Grafindo Persada.

[9] Triton P. Budi. (2006). SPSS 13.0. Terapan: Riste Statistik Parametrik. Yogyakarta: CV. Andi Offset. 